\author{
KATARZYNA ŁOBACZ \\ Uniwersytet Szczeciński, Polska \\ University of Szczecin, Poland

\section{PIOTR NiEDZIELSKI} \\ Uniwersytet Szczeciński, Polska \\ University of Szczecin, Poland
}

\title{
Transfer kapitału ludzkiego z międzynarodowych centrów usług jako czynnik kształtowania konkurencyjności MMŚP w regionie zachodniopomorskim
}

\section{Transfer of Human Capital from the Multinational Service Centres and the Competitiveness of MSME in the West-Pomeranian Region}

\begin{abstract}
Streszczenie: Polska znajduje się obecnie w czołówce miejsc w Europie Środkowo-Wschodniej, w których lokalizują się międzynarodowe centra usług. Wynika z tego istotne znaczenie analizowania wpływu, jaki mają one na rozwój polskiej gospodarki. Jednym z istotnych efektów wynikających z obecności centrów usług jest przepływ wiedzy, w tym jej transfer do sektora mikro-, małych i średnich przedsiębiorstw (MMŚP) - wiedzy, która odgrywa coraz ważniejszą rolę w procesie kształtowania konkurencyjności, tak w ujęciu mikro-, jak i makroekonomicznym. Celem artykułu jest zatem analiza interakcji zachodzących pomiędzy centrami usług o międzynarodowym zasięgu a mniejszymi podmiotami funkcjonującymi w gospodarkach lokalnych. Szczególny nacisk położony został na przepływ wiedzy ukrytej wynikający z transferu kapitału ludzkiego pomiędzy centrami usług a mikro-, małymi i średnimi przedsiębiorstwami zlokalizowanymi w regionie zachodniopomorskim. W opracowaniu wykorzystano badania ilościowe zrealizowane w latach 2013-2016 na próbie reprezentatywnej regionu. Wyniki badań wskazują, że występuje istotny statystycznie związek pomiędzy badanymi zmiennymi. Ukazują one, iż firmy, których właściciele lub pracownicy mają doświadczenia związane z pracą w międzynarodowych centrach usług, doświadczają bardziej dynamicznego wzrostu obrotów oraz wprowadzają na rynek więcej nowych produktów. Ma to wpływ na konkurencyjność tychże podmiotów, również w ujęciu międzynarodowym.
\end{abstract}

\footnotetext{
Abstract: Poland is currently at the forefront of places in Central and Eastern Europe, where international service centres are located. This shows the importance of analysing the impact they have on the development of the Polish economy. One of the important effects resulting from the presence of service centres is the flow of knowledge, including its transfer to the MSME sector - knowledge, which plays an increasingly important role in the process of shaping competitiveness, both in micro- and macroeconomic terms. The aim of the article is therefore to analyse the interactions between service centres with international coverage and smaller entities operating in local economies. Particular emphasis was placed on the flow of hidden knowledge resulting from the transfer of human capital between service centres and micro-, small- and medium enterprises located in the West Pomeranian region. The study uses quantitative research conducted in the years 2013-2016 on a representative sample of companies in the region. The research results indicate that there is a statistically significant relationship between the variables studied. They show that companies whose owners or employees have work experience in international service centres exhibit a more dynamic growth
} 
in turnover and bring more new products to the market. This has an impact on the competitiveness of these entities, also at the international arena.

Klasyfikacja JEL: F61, 019, J24

Słowa kluczowe: centra usług; efekty spillovers; innowacyjność sektor MMŚP; konkurencyjność; transfer kapitału ludzkiego; transfer wiedzy

Keywords: competitiveness; innovativeness; MSME; service centres; spillovers; transfer of human capital; transfer of knowledge

Otrzymano: 17 lutego 2019

Received: 17 February 2019

Zaakceptowano: 28 maja 2019

Accepted: 28 May 2019

\section{Sugerowana cytacja / Suggested citation:}

Łobacz, K., Niedzielski, P. (2019). Transfer kapitału ludzkiego z międzynarodowych centrów usług jako czynnik kształtowania konkurencyjności MMŚP w regionie zachodniopomorskim. Prace Komisji Geografii Przemysłu Polskiego Towarzystwa Geograficznego, 33(3), 70-84. doi: 10.24917/20801653.333.5

\section{WSTĘP}

Polska jest obecnie liderem w lokalizacji centrów usług w Europie Środkowo-Wschodniej, a ich oddziaływanie ma zróżnicowany charakter, znacznie szerszy niż ten związany z przyrostem liczby miejsc pracy (ABSL, 2016). Jednym z efektów o dużym znaczeniu jest przepływ wiedzy, w tym do sektora MMŚP (Rugraff, Hansen, 2011; Sass, 2011). Mikro-, małe i średnie przedsiębiorstwa budują przewagę konkurencyjną, wykorzystując swoje naturalne walory, takie jak zwinność, zdolność do szybkiego reagowania i dostosowywania się do zmian w otoczeniu, a także zasoby niematerialne i zdolności behawioralne, skąd wynika istotna rola wiedzy w ich procesach konkurowania.

$\mathrm{Z}$ punktu widzenia roli, jaką centra usług odgrywają w procesach gospodarczych, zdefiniować je należy jako firmy realizujące zadania związane z ciągłą obsługą procesów biznesowych innych, zwykle dużych firm. Ich rolą jest obsługa procesów, bez których firmy nie są w stanie funkcjonować i których realizacja (sposób realizacji) wpływa na wykonanie pozostałych procesów w firmie. Mogą one obsługiwać wyspecjalizowane rodzaje procesów lub ich grupę, zaliczane w przedsiębiorstwie do procesów usługowych, jak np. obsługa klienta, logistyka, procesy finansowe, obsługa IT. Outsourcingowane procesy i usługi mają charakter wysoce wystandaryzowany, co oznacza, że szczególną podatność wykazują tu procesy o charakterze jednorodnym, odbywające się według zasad, które mogą być precyzyjnie zdefiniowane i skodyfikowane. Te wszystkie cechy sprawiają, że w centrach usług następuje wysoka kumulacja wiedzy związanej z procesami usługowymi, $w$ tym wykorzystaniem technologii, które te procesy usprawniają (Niedzielski, Łobacz, 2017).

Zagadnienie dotyczące wpływu centrów usług na rozwój podmiotów w otoczeniu i całych województw jest zagadnieniem stosunkowo nowym w polskiej i zagranicznej literaturze przedmiotu. W dorobku polskiego piśmiennictwa naukowego można znaleźć nieliczne pozycje dotyczące zasad działania centrów usług. Chociaż istnieje dorobek traktujący centra usług całościowo jako jedną z grup podmiotów funkcjonujących w gospodarce, nie analizuje on jednak w dostatecznym stopniu procesów zachodzących na styku tych podmiotów z małymi przedsiębiorstwami, m.in. procesów związanych z przepływem wiedzy. 
Celem artykułu jest zatem analiza tychże procesów, ze szczególnym naciskiem na przepływ wiedzy ukrytej wynikający z transferu kapitału ludzkiego pomiędzy centrami usług a mikro-, małymi i średnimi przedsiębiorstwami zlokalizowanymi na terenie regionu zachodniopomorskiego. W opracowaniu wykorzystano badania ilościowe zrealizowane w latach 2013-2016 na próbie reprezentatywnej firm z grupy MMŚP zlokalizowanych na terenie województwa. Zostały one przeprowadzone z wykorzystaniem techniki CATI, a uzyskane wyniki poddano analizie statystycznej. W odniesieniu do efektów będących rezultatem przepływu wiedzy szczególną uwagę zwrócono na dwa aspekty konkurencyjności przedsiębiorstw, tj. innowacyjność i wzrost ${ }^{1}$.

\section{KONKURENCYJNOŚĆ MMŚP W ASPEKCIE WPŁYWU MIĘDZYNARODOWYCH CENTRÓW USŁUG}

Wyjaśnienie zjawiska konkurencji w procesach gospodarowania stanowiła i stanowi kluczowy przedmiot zainteresowania teorii i praktyki co najmniej dwóch dyscyplin naukowych, czyli ekonomii i finansów oraz nauk o zarządzaniu i jakości (Stankiewicz, 2002; Dzikowska, Gorynia, 2012). Sam termin „konkurencja”, wywodzący się od łacińskiego słowa concurrentia, oznaczającego „biec razem” w rozumieniu współzawodnictwa (Stankiewicz, 2002), ma swoje bezpośrednie odniesienie do działań biznesowych. Zjawisko konkurencyjności występuje, gdy uczestnicy rynku (mechanizmów rynkowych) rywalizują między sobą w dążeniach do analogicznych celów, co oznacza, że działania podejmowane przez jednych uczestników rynku dla osiągnięcia swoich celów utrudniają (a nawet uniemożliwiają) osiąganie takich samych celów innym (Stankiewicz, 2002).

W kontekście konkurencyjności wskazuje się, że przedsiębiorstwo ma potencjał konkurencyjny definiowany jako ogół zasobów materialnych i niematerialnych (Kunasz, 2006). Zasoby przedsiębiorstwa są w literaturze przedmiotu opisywane z różnych punktów widzenia, a ich wachlarz jest szeroki, od aktywów trwałych, maszyn i urządzeń, przez zasoby finansowe, zapasy, pracowników wraz z ich kompetencjami, po wiedzę o procesach techniczno-technologicznych, procedury, wiedzę o rynku, powiązania rynkowe, kontakty handlowe czy markę firmy. Przy pewnym uproszczeniu wyróżnia się trzy zasadnicze grupy zasobów (Barney, 1992):

- zasoby kapitału fizycznego (zasoby materialne),

- zasoby kapitału ludzkiego (zasoby ludzkie),

- zasoby kapitału organizacyjnego (zasoby niematerialne).

Konkurencyjność przedsiębiorstw w podejściu zasobowym związana jest ze zjawiskiem heterogeniczności, które wynika z faktu nierównomierności rozłożenia zasobów na poszczególne przedsiębiorstwa oraz wewnątrz firm. Ponadto zasoby nie są doskonale mobilne, co oznacza, że nie jest możliwe ich dowolne przeniesienie pomiędzy przedsiębiorstwami lub wykorzystanie do dowolnych procesów w konkretnym podmiocie gospodarczym. W obecnych uwarunkowaniach gospodarczych (tj. w warunkach rozwoju gospodarki opartej na wiedzy) coraz większe znaczenie w procesach gospodarowania ma wiedza, którą w powyższym ujęciu należy umiejscowić w kapitale

\footnotetext{
${ }^{1}$ Niniejszy artykuł powstał w oparciu o badania przeprowadzone w ramach projektu finansowanego ze środków NCN przyznanych na podstawie decyzji nr DEC-2011/03/B/HS4/05890. Szerokie wnioski z badań zaprezentowano w Niedzielski i Łobacz (2017), a niniejszy artykuł przedstawia wybrane i pogłębione wnioski niniejszego studium.
} 
organizacyjnym oraz w kapitale ludzkim. Zarządzanie wiedzą i budowa kompetencji przedsiębiorstwa, umiejętność szukania okazji rynkowych i ich efektywnego wykorzystania czy też diagnozowania nisz rynkowych są narzędziem kształtowania konkurencyjności przedsiębiorstw sektora MMŚP na globalizującym się współczesnym rynku.

Już w 1962 roku K. Arrow wskazał, że wiedza jest zasadniczo inna niż pozostałe czynniki produkcji. Ta specyfika wynika z jej cech, do których zaliczyć należy przede wszystkim jej niematerialny charakter, który implikuje jej stosunkowo łatwą powielarność oraz w dużej części niewykluczalność, która w konsekwencji prowadzi do szybkiego wzrostu ilości ogólnego zasobu wiedzy (Arrow, 1962; Romer, 1986). Wiedza stanowi podstawę rozwoju, będąc impulsem do tworzenia innowacji, początkowo o charakterze radykalnym, później naśladowczym (Schumpeter, 1939).

Nowa wiedza tworzy nowe okazje rynkowe, które w różnym stopniu i w różny sposób są wykorzystywane przez podmioty gospodarcze (Arrow, 1962; Acs, Braunerhjelm, Audrechts, Carlsson, 2009). Nowa wiedza pozwala także dostrzec okazje, które wcześniej nie były widoczne. Wiedza prowadzi ponadto do podwyższenia efektywności realizowanych działań. Co do zasady wytworzenie nowej wiedzy wymaga inwestycji ponoszonych przez podmioty nią zainteresowane. Z właściwości wiedzy wynika jednak możliwość korzystania z niej bez konieczności inwestowania. W tym kontekście mówi się o występowaniu tzw. efektów spillovers, czyli rozprzestrzenianiu się pewnych cząstek wiedzy na podmioty trzecie, czyli takie, które nie poniosły kosztów związanych z jej wytworzeniem.

Badania pokazują, że efekty spillovers występują w dużej intensywności w obszarze oddziaływania większych firm (Acs, Braunerhjelm, Audrechts, Carlsson, 2009). Wskazuje się tutaj szczególną rolę firm technologicznych, aktywnie zaangażowanych w tworzenie nowej wiedzy o charakterze technologicznym. Można zatem przypuszczać, że w odniesieniu do firm usługowych taką rolę mogą pełnić tzw. centra usług, będące dużymi podmiotami gospodarczymi, wspierającymi w sposób profesjonalny realizację funkcji usługowych innych większych podmiotów i stosujące w związku z tym zaawansowane systemy zarządzania procesem ich świadczenia, a dodatkowo mające wystarczający potencjał do inwestowania w wytworzenie wiedzy i jej świadomą akumulację. Oznacza to, że takie centra mogą być źródłem nowych okazji rynkowych lub wiedzy o istniejących okazjach, które zostaną wykorzystane przez istniejące lub nowo tworzone podmioty gospodarcze, będące w obszarze ich oddziaływania. Mogą być również źródłem wiedzy procesowej, która w przypadku usług odgrywa niezwykle istotną rolę, przekładając się na innowacyjność i efektywność realizowanych działań. Mogą być wreszcie źródłem wiedzy o rynkach czy klientach, których potrzeby są niezaspokojone lub niewystarczająco zaspokojone przez istniejące produkty lub usługi, która niesie potencjał dynamiczniejszego wzrostu w krótszym okresie.

Literatura przedmiotu wskazuje wiele efektów oddziaływania korporacji międzynarodowych, w tym centrów usług, na lokalne mikro-, małe i średnie podmioty gospodarcze (np. Navaretti, Venables, 2004; Sass, 2011; Niedzielski, Łobacz, 2017), które wiązane są z występowaniem między nimi bezpośrednich interakcji. Jednak lokalne firmy mogą odnosić korzyści z bliskości funkcjonowania korporacji międzynarodowych nawet pomimo braku ich bezpośredniej interakcji lub bardzo ograniczonego jej zakresu. Korzyści te mogą bowiem wynikać z samego faktu znajdowania się we wspólnym otoczeniu konkurencyjnym albo obserwowania realizowanych przez inne podmioty (osoby) działań i ich efektów (Rugraff, Hansen, 2011). Dodatkowo istotną rolę 
odgrywać może transfer kapitału ludzkiego z centrów usług do blisko zlokalizowanych MMŚP, który ma szczególny potencjał przenoszenia pomiędzy organizacjami wiedzy o charakterze ukrytym (tzw. tacit knowledge).

Hipoteza ta zostanie poddana weryfikacji w dalszej części opracowania na podstawie wyników badań przeprowadzonych na obszarze regionu zachodniopomorskiego.

\section{Metodologia BADAŃ}

W ramach przeprowadzonych badań analizie poddano wpływ transferu kapitału ludzkiego pomiędzy centrami usług a firmami sektora MMŚP na ich aspekty konkurencyjności, tj. innowacyjność i wzrost. Innowacyjność mierzono zaangażowaniem w rozwijanie i wdrażanie nowych produktów przez mikro-, małe i średnie przedsiębiorstwa, wzrost natomiast za pomocą zmiennej obrazującej zmianę wartości obrotów przedsiębiorstwa. W obu przypadkach stan obecny porównano do stanu sprzed trzech lat, co pozwoliło określić zmianę wartościową, która dokonała się we wskazanym okresie.

Transfer kapitału ludzkiego zidentyfikowano przez odnotowanie $\mathrm{w}$ firmach sektora MMŚP osób, które wcześniej były zatrudnione w dowolnym międzynarodowym centrum usług. Strategiczny wymiar transferowanej wiedzy określono przez zróżnicowanie stanowisk i ról piastowanych w jednej i drugiej organizacji. W odniesieniu do zatrudnienia w centrum usług wyodrębniono trzy rodzaje zajmowanych pozycji: praca operacyjna, zarządzanie działem lub zespołem, zarządzanie firmą. W przypadku zaangażowania w działania firm sektora MMŚP wyróżniono dwie podstawowe role: właściciela i pracownika, przy czym właścicieli podzielono dodatkowo na założycieli firmy oraz właścicieli, którzy dołączyli do grona wspólników po utworzeniu firmy.

Badania zostały przeprowadzone z wykorzystaniem techniki CATI. Kwestionariuszowy wywiad telefoniczny wspomagany komputerowo przeprowadzony został z wykorzystaniem specjalistycznego oprogramowania badawczo-analitycznego. Umożliwiło to realizację wielu scenariuszy wywiadów, w zależności od występowania poszczególnych zjawisk, kluczowych dla przedmiotu badania. Dane pozyskane w procesie badawczym poddano statystycznej analizie danych oraz statystycznej analizie porównawczej.

W zrealizowanych badaniach jednostką analizy była organizacja, czyli mikro-, mały lub średni podmiot gospodarczy, mający swoją siedzibę lub oddział regionalny na terenie województwa zachodniopomorskiego. Zgodnie z przyjętą w koncepcji procesu badawczego jednostką analizy w badaniach ilościowych przyjęto dobór próby badawczej, umożliwiający uogólnianie wniosków na całą populację. Spośród operatu (listy mikro-, małych i średnic przedsiębiorstw mających siedzibę lub oddział regionalny na obszarze województwa zachodniopomorskiego) przeprowadzono wywiady z 1100 przedsiębiorstwami, przy założeniu minimalnej liczebności próby badawczej na poziomie 1062 przedsiębiorstw.

Rzetelność zrealizowanej próby badawczej w badaniach sondażowych możliwa jest do weryfikacji na podstawie poziomu zbieżności rozkładu częstości kluczowych cech charakteryzujących przebadane przedsiębiorstwa (tj. wagi w próbie) z odpowiadającymi im parametrami w populacji. Dobór próby do badania ilościowego uwzględniał następujące parametry: wielkość przedsiębiorstwa (liczba osób zatrudnionych), lokalizacja siedziby przedsiębiorstwa, jego obszar działalności. Szczegóły próby zestawiono w tabeli 1. 
Tabela 1. Udział grup przedsiębiorstw w próbie badawczej

\begin{tabular}{|l|c|c|}
\hline $\begin{array}{c}\text { Wielkość przedsiębiorstw: liczba } \\
\text { osób zatrudnionych }\end{array}$ & $\begin{array}{c}\text { Odsetek przedsiębiorstw } \\
\text { w województwie } \\
\text { zachodniopomorskim w 2016 } \\
\text { roku }\end{array}$ & $\begin{array}{c}\text { Odsetek przedsiębiorstw objętych } \\
\text { badaniem }\end{array}$ \\
\hline mikro (0-9 osób) & $96,3 \%$ & $82,3 \%$ \\
\hline małe (10-49 osób) & $3,0 \%$ & $12,9 \%$ \\
\hline średnie (50-249 osób) & $0,6 \%$ & $4,8 \%$ \\
\hline duże (powyżej 250 osób) & $0,1 \%$ & $0 \%$ \\
\hline Ogółem & $100 \%$ & $100 \%$ \\
\hline
\end{tabular}

Źródło: opracowanie własne na podstawie danych GUS

W przypadku struktury wielkości przedsiębiorstw ze względu na liczbę osób zatrudnionych występuje nadreprezentacja małych i średnich podmiotów, co stanowiło celowy zamysł badaczy. Wynikało bowiem z potrzeby uzyskania danych porównawczych odnośnie do zachodzenia badanych zjawisk pomiędzy poszczególnymi kategoriami podmiotów (mikro-, małymi i średnimi), co byłoby niemożliwe w przypadku przyjęcia odsetka zgodnego z rozkładem częstości cech w populacji w odniesieniu do wielkości próby badawczej. Pomimo zastosowanego zabiegu nałożenia wagi w próbie struktura wielkości badanych przedsiębiorstw nie odbiega w znaczny sposób od parametrów populacji.

Lokalizacja siedziby przedsiębiorstwa stanowiła podstawowy mechanizm losowania firm do realizacji pomiaru (przez wybór połączeń telefonicznych z podmiotami z poszczególnych miejscowości regionu) i odzwierciedlała rozkład liczby przedsiębiorstw w województwie zachodniopomorskim na poziomie powiatów. Szczegółową strukturę przedstawiono $\mathrm{w}$ tabeli 2 .

Tabela 2. Struktura próby badawczej - lokalizacja siedziby przedsiębiorstwa

\begin{tabular}{|l|c|c|}
\hline \multicolumn{1}{|c|}{$\begin{array}{c}\text { Powiaty województwa } \\
\text { zachodniopomorskiego }\end{array}$} & $\begin{array}{c}\text { Odsetek przedsiębiorstw } \\
\text { w województwie } \\
\text { zachodnopomorskim w podziale } \\
\text { na lokalizację }\end{array}$ & $\begin{array}{c}\text { Odsetek przedsiębiorstw objętych } \\
\text { badaniem }\end{array}$ \\
\hline Powiat białogardzki & $2,2 \%$ & $2,2 \%$ \\
\hline Powiat kołobrzeski & $5,7 \%$ & $5,7 \%$ \\
\hline Powiat koszaliński & $3,3 \%$ & $3,3 \%$ \\
\hline Powiat sławieński & $2,7 \%$ & $2,6 \%$ \\
\hline Powiat m. Koszalin & $8,3 \%$ & $8,3 \%$ \\
\hline Powiat choszczeński & $1,9 \%$ & $1,9 \%$ \\
\hline Powiat drawski & $2,7 \%$ & $2,6 \%$ \\
\hline Powiat myśliborski & $3,1 \%$ & $3,1 \%$ \\
\hline Powiat pyrzycki & $1,7 \%$ & $1,7 \%$ \\
\hline Powiat szczecinecki & $3,6 \%$ & $3,6 \%$ \\
\hline Powiat świdwiński & $2,0 \%$ & $2,0 \%$ \\
\hline Powiat wałecki & $2,6 \%$ & $2,6 \%$ \\
\hline Powiat łobeski & $1,5 \%$ & $1,5 \%$ \\
\hline Powiat m. Szczecin & $30,8 \%$ & $30,8 \%$ \\
\hline Powiat goleniowski & $4,0 \%$ & $4,0 \%$ \\
\hline
\end{tabular}




\begin{tabular}{|l|c|c|}
\hline Powiat gryficki & $3,5 \%$ & $3,5 \%$ \\
\hline Powiat gryfiński & $3,9 \%$ & $3,9 \%$ \\
\hline Powiat kamieński & $3,2 \%$ & $3,2 \%$ \\
\hline Powiat policki & $4,8 \%$ & $4,8 \%$ \\
\hline Powiat stargardzki & $5,6 \%$ & $5,5 \%$ \\
\hline Powiat m. Świnoujście & $2,9 \%$ & $2,9 \%$ \\
\hline Ogółem & $100 \%$ & $100 \%$ \\
\hline
\end{tabular}

Źródło: opracowanie własne na podstawie danych GUS

Struktura przedsiębiorstw uczestniczących w badaniu w zestawieniu z przedsiębiorstwami w województwie zachodniopomorskim pod względem obszaru działalności jest również zbieżna, co oznacza, że przedstawiony w niniejszym opracowaniu obraz rzeczywistości społeczno-gospodarczej województwa najprawdopodobniej nie odbiega od stanu faktycznego. Odpowiednie porównanie przedstawiono w tabeli 3.

Tabela 3. Struktura próby badawczej - obszar działalności przedsiębiorstwa

\begin{tabular}{|l|c|c|}
\hline \multicolumn{1}{|c|}{ Sekcja; obszar działalności } & \multicolumn{1}{|c|}{$\begin{array}{c}\text { Odsetek przedsiębiorstw } \\
\text { w województwie } \\
\text { zachodniopomorskim w } 2014 \\
\text { roku }\end{array}$} & $\begin{array}{c}\text { Odsetek przedsiębiorstw objętych } \\
\text { badaniem }\end{array}$ \\
\hline Przetwórstwo przemysłowe & $8,0 \%$ & $7,9 \%$ \\
\hline Budownictwo & $12,5 \%$ & $12,6 \%$ \\
\hline $\begin{array}{l}\text { Handel, naprawa pojazdów } \\
\text { samochodowych }\end{array}$ & $23,3 \%$ & $22,9 \%$ \\
\hline $\begin{array}{l}\text { Transport i gospodarka } \\
\text { magazynowa }\end{array}$ & $6,3 \%$ & $6,5 \%$ \\
\hline Obsługa rynku nieruchomości & $7,3 \%$ & $7,3 \%$ \\
\hline $\begin{array}{l}\text { Działalność profesjonalna, } \\
\text { naukowa i techniczna }\end{array}$ & $7,8 \%$ & $8,0 \%$ \\
\hline Pozostała działalność usługowa & $6,1 \%$ & $6,3 \%$ \\
\hline Pozostałe sekcje & $28,7 \%$ & $28,5 \%$ \\
\hline Ogółem & $100 \%$ & $100 \%$ \\
\hline
\end{tabular}

Źródło: opracowanie własne na podstawie danych GUS

Można zatem przyjąć, że próba badawcza została zrealizowana na wysokim poziomie rzetelności. Zarówno wylosowana, jak i zrealizowana próba badawcza jest w wysokim stopniu zbieżna ze strukturą rzeczywistego obrazu przedsiębiorstw w województwie zachodniopomorskim. Tym samym można uznać reprezentatywny charakter próby.

\section{TRANSFER KAPITAŁU LUDZKIEGO Z MIĘDZYNARODOWYCH CENTRÓW USŁUG A WZROST MMŚP}

Kapitał wiedzy wynikający z doświadczenia pracy w centrach usług może być źródłem wzrostu firm sektora MMŚP. Znajomość określonych sposobów zarządzania procesami biznesowymi w centrach usług lub korporacjach może wpływać na sposób podejmowania decyzji strategicznych i operacyjnych. Wzrost ten mierzyć można zmianą 
wartości obrotu następującą w określonym czasie. W przedmiotowym badaniu zmianę tę odniesiono do stanu sprzed trzech lat.

Badania przeprowadzone na próbie przedsiębiorstw województwa zachodniopomorskiego wskazują, iż istotnie może występować taka zależność. Wynika z nich, że właściciele zachodniopomorskich firm sektora MMŚP z doświadczeniem pracy w centrach usług znacznie częściej odnotowywali wzrost obrotu $(88,9 \%)$, niż właściciele z doświadczeniem zatrudnienia w korporacjach (45,5\%). Wskazany związek statystyczny (Chi kwadrat $=76,102)$ należy oceniać jako słaby $(\mathrm{R}$ Pearsona $=0,182)$, jednak wartość tę trzeba odczytywać z uwzględnieniem niewielkiej liczebności próby firm spełniających wymagane kryteria. Dane pokazujące tą zależność zestawiono w tabeli 4.

Tabela 4. Zmiana wartości obrotu firmy w trzech ostatnich latach w zależności od doświadczenia zatrudnienia właścicieli w korporacjach, w tym w centrach usług

\begin{tabular}{|c|c|c|c|c|}
\hline \multirow{2}{*}{\multicolumn{2}{|c|}{ Dane w \% }} & \multicolumn{3}{|c|}{$\begin{array}{l}\text { Firmy, których wartość obrotu } \\
\text { w trzech ostatnich latach }\end{array}$} \\
\hline & & \multirow{2}{*}{$\begin{array}{c}\text { wzrosła } \\
45,5\end{array}$} & \multirow{2}{*}{$\frac{\text { nie zmieniła się }}{31,8}$} & \multirow{2}{*}{$\begin{array}{l}\text { spadła } \\
10,0\end{array}$} \\
\hline Firmy, których właściciele mają & tak & & & \\
\hline doświadczenie związane z pracą w korporacji & nie & 23,2 & 36,5 & 24,7 \\
\hline \multirow{3}{*}{$\begin{array}{l}\text { Firmy, których właściciele mają } \\
\text { doświadczenie związane z pracą w centrach } \\
\text { usług }\end{array}$} & tak & 88,9 & 11,1 & 0,0 \\
\hline & nie & 24,4 & 35,8 & 22,4 \\
\hline & ogółem & 24,9 & 35,6 & 22,2 \\
\hline
\end{tabular}

Źródło: opracowanie własne

Wzrost obrotu jest szczególnie widoczny w tych podmiotach, których właściciele mają doświadczenie zatrudnienia w centrach usług, co może świadczyć o wykorzystaniu wiedzy i doświadczenia tam zdobytych, które umożliwiają zarządzanie firmą w sposób bardziej efektywny lub stosowanie strategii pozwalających firmom na szybszy rozwój. Warto zatem odpowiedzieć na pytanie, czy istnieje związek pomiędzy charakterem pracy wykonywanej w centrum usług lub ogólnie w firmie o charakterze korporacyjnym przez obecnych właścicieli MMŚP a uzyskiwanymi przez te firmy rezultatami. Zależność tę zobrazowano w tabeli 5.

Tabela 5. Zmiana wartości obrotu MMŚP w trzech ostatnich latach w zależności od charakteru pracy wykonywanej przez ich właścicieli w korporacjach, w tym w centrach usług

\begin{tabular}{|c|c|c|c|c|}
\hline \multirow{2}{*}{\multicolumn{2}{|c|}{ Dane w \% }} & \multicolumn{3}{|c|}{$\begin{array}{c}\text { Firmy, których wartość obrotu } \\
\text { w trzech ostatnich latach }\end{array}$} \\
\hline & & wzrosła & nie zmieniła się & spadła \\
\hline \multirow{3}{*}{$\begin{array}{l}\text { Firmy, których właściciele } \\
\text { mają doświadczenie związane } \\
\text { z pracą w korporacji } \\
\text { o określonej charakterystyce }\end{array}$} & Praca operacyjna & 43,6 & 35,9 & 5,1 \\
\hline & $\begin{array}{l}\text { Zarządzanie zespołem/ } \\
\text { działem }\end{array}$ & 57,7 & 25,0 & 11,5 \\
\hline & Zarządzanie firmą & 50,0 & 31,8 & 4,5 \\
\hline \multirow{3}{*}{$\begin{array}{l}\text { Firmy, których właściciele } \\
\text { mają doświadczenie związane } \\
\text { z pracą w centrach usług } \\
\text { o określonej charakterystyce }\end{array}$} & Praca operacyjna & 85,7 & 14,3 & 0,0 \\
\hline & $\begin{array}{l}\text { Zarządzanie zespołem/ } \\
\text { działem }\end{array}$ & 100,0 & 0,0 & 0,0 \\
\hline & Zarządzanie firmą & 100,0 & 0,0 & 0,0 \\
\hline
\end{tabular}

Źródło: opracowanie własne 
Doświadczenie pracy w centrach usług zdaje się potwierdzać ustalenia dotyczące wpływu tejże zmiennej na wzrost firm. Właściciele z doświadczeniem pracy w centrach usług, pełniący różne funkcje, znacznie częściej odnotowują wzrost wartości obrotu niż właściciele, którzy mają doświadczenie w pracy w korporacjach. Bez znaczenia wydaje się być dotychczas pełnione stanowisko w centrum usług.

Również dane przedstawione w tabeli 6 zdają się potwierdzać hipotezę dotyczącą wpływu doświadczenia w pracy w centrach usług na rozwój przedsiębiorstw. Wartość środkowa zadeklarowanego wzrostu obrotu, wyrażona w procentach, dla wszystkich badanych firm wynosi 20, zaś dla firm, których właściciele mają doświadczenie w pracy w korporacjach lub centrach usług, jest wyższa i wynosi odpowiednio 27,5 i 30. Wyraźnie widoczny jest wzrost wartości obrotu w firmach, których właściciele mają doświadczenie zatrudnienia w centrach usług, niż w przedsiębiorstwach, których właściciele nie mają takiego doświadczenia. Wydaje się, że wiedza i umiejętności zdobyte na skutek pracy w centrach usług lub korporacjach mogą przyczyniać się do zwiększenia poziomu efektywności poszczególnych procesów biznesowych i ekspansji rynkowej firmy.

Tabela 6. Zmiana wartości obrotu firmy w trzech ostatnich latach w zależności od doświadczenia zatrudnienia właścicieli w korporacjach, w tym w centrach usług

\begin{tabular}{|l|c|c|c|}
\hline \multicolumn{1}{|c|}{ Dane w \% - wartość wzrostu obrotów } & średnia & $\begin{array}{c}\text { odchylenie } \\
\text { standardowe }\end{array}$ & mediana \\
\hline Firmy, które zadeklarowały wzrost obrotu ogółem & 48,1 & 302,8 & 20,0 \\
\hline $\begin{array}{l}\text { w tym: firmy, których właściciele mieli } \\
\text { doświadczenie pracy w korporacji }\end{array}$ & 48,9 & 61,6 & 30,0 \\
\hline $\begin{array}{l}\text { w tym: firmy, których właściciele mieli } \\
\text { doświadczenie pracy centrach usług }\end{array}$ & 61,3 & 97,1 & 27,5 \\
\hline $\begin{array}{l}\text { w tym: firmy, których właściciele nie mieli } \\
\text { doświadczenia pracy w żadnej firmie o charakterze } \\
\text { korporacyjnym }\end{array}$ & 48,2 & 341,1 & 20,0 \\
\hline
\end{tabular}

Źródło: opracowanie własne

Dane zdają się ponadto potwierdzać, że również pracownicy zatrudnieni obecnie w firmach sektora MMŚP, a mający wcześniejsze doświadczenia zawodowe w firmach o charakterze korporacyjnym, w tym szczególnie w centrach sług, wnoszą do obecnej organizacji wartość, przekładającą się na wzrost obrotów mniejszych podmiotów, co obrazują dane zestawione w tabeli 7.

Tabela 7. Zmiana wartości obrotu firmy w trzech ostatnich latach w zależności od doświadczenia zatrudnienia pracowników w korporacjach, w tym w centrach usług

\begin{tabular}{|l|c|c|c|c|}
\hline \multirow{2}{*}{\multicolumn{2}{|c|}{}} & \multicolumn{3}{|c|}{$\begin{array}{c}\text { Firmy, których wartość obrotu } \\
\text { w trzech ostatnich latach }\end{array}$} \\
\cline { 3 - 5 } & & wzrosła & nie zmieniła się & spadła \\
\hline $\begin{array}{l}\text { Firmy, których pracownicy mają doświadczenie } \\
\text { związane z pracą w korporacji }\end{array}$ & tak & 55,7 & 21,3 & 9,8 \\
\cline { 2 - 5 } $\begin{array}{l}\text { Firmy, których pracownicy mają doświadczenie } \\
\text { związane z pracą w centrach usług }\end{array}$ & nie & 22,8 & 35,8 & 24,2 \\
\cline { 2 - 5 } & tak & 100,0 & 0,0 & 0,0 \\
\hline
\end{tabular}

Źródło: opracowanie własne 
Wynika z nich, ponownie przy zachowaniu pewnej ostrożności interpretacyjnej, że zachodniopomorskie firmy z sektora MMŚP, których pracownicy mają doświadczenie pracy w centrach usług, znacznie częściej odnotowują wzrost obrotu (100\%) niż te podmioty, których pracownicy mają doświadczenie w pracy w korporacjach $(55,7 \%)$. Wskazany związek statystyczny (Chi kwadrat $=48,681$ ) należy oceniać jako słaby (R Pearsona $=0,120$ ), chociaż zdaje się odzwierciedlać rzeczywistość. Z kolei odsetek firm, których właściciele nie mają doświadczenia w pracy w centrach usług lub korporacjach i odnotowały wzrost obrotu, nie przekracza $24,5 \%$.

\section{TRANSFER KAPITAŁU LUDZKIEGO Z MIĘDZYNARODOWYCH CENTRÓW USŁUG A INNOWACYJNOŚĆ MMŚP}

Innowacyjność firm, w tym szczególnie firm małych i średnich, zależy od kapitału wiedzy, na którym opierają swoje działania (Łobacz, 2012; Głodek, 2018). Wiedza o różnym charakterze stanowi podstawę i (lub) źródło działań rozwojowych podmiotów gospodarczych (Łobacz, 2015; Łobacz, Głodek, Stawasz, Niedzielski, 2016; Distanont, Khongmalai, 2018). Dlatego efekty zewnętrzne wynikające z przepływu wiedzy stanowią ważną podstawę rozwoju mikro-, małych i średnich firm.

W przeprowadzonym badaniu przeanalizowano grupy mikro-, małych i średnich przedsiębiorstw, w których wystąpiło prawdopodobieństwo przepływu wiedzy przez transfer kapitału ludzkiego w odniesieniu do tych, które nie miały takich doświadczeń, i zestawiono je ze zmienną obrazującą fakt wprowadzenia na rynek nowych produktów.

W tabeli 8 przedstawiono porównanie firm, których właściciele mają doświadczenia związane z pracą w korporacjach ogółem lub ich nie mają oraz, osobno, w centrach usług w odniesieniu do ich działań nakierowanych na wprowadzenie na rynek nowych produktów. Uzyskane wyniki sugerują występowanie efektów wynikających z transferu wiedzy z firm korporacyjnych, w tym szczególnie tych o charakterze usługowym.

Z danych wynika, że większy odsetek właścicieli zachodniopomorskich firm sektora MMŚP, którzy mają doświadczenie zatrudnienia w centrach usług, wprowadziło na rynek nowe produkty (50\%) niż tych właścicieli, którzy mają doświadczenie pracy ogólnie w korporacjach $(35,4 \%)$. Dla porównania warto zaznaczyć, że średnio co piąty właściciel przedsiębiorstwa z regionu Pomorza Zachodniego $(22,6 \%)$ wprowadził na rynek nowe produkty. Pomimo iż wskazane zjawisko należy oceniać w kategoriach słabego związku statystycznego ( $\mathrm{R}$ Pearsona $=-0,104$ ), liczba nowych produktów wprowadzanych na rynek jest większa, kiedy osoby miały doświadczenia związane z pracą w korporacji lub centrum usług (test Chi kwadrat = 11,097). Powyżej pięciu nowych produktów wdrożyło 8,7\% firm, które współpracowały z korporacją, a jedynie 4,9\% firm niemających takich doświadczeń.

Bardziej szczegółowego obrazu sytuacji dostarcza analiza charakteru pracy wykonywanej przez obecnych właścicieli przedsiębiorstw sektora MMŚP w firmach korporacyjnych. Dane pokazano w tabeli 9.

Wynika z nich, że wprowadzanie na rynek nowych produktów jest także determinowane zakresem obowiązków wykonywanych przez właściciela firmy z doświadczeniem pracy w centrach usług. Obecni właściciele MMŚP deklarujący uczestniczenie w zarządzaniu firmą podczas pracy w centrach usług, w 100\% realizowali działania 
innowacyjne w swoich obecnych firmach. Odsetek małych i średnich firm zaangażowanych we wdrażanie na rynek nowych rozwiązań wśród tych kierowanych przez właścicieli z doświadczeniami w zakresie zarządzania działem lub zespołem w centrach usług jest również wysoki i wynosi 60\%. Udział firm innowacyjnych wśród tych, których właściciele wykonywali w centrach usług pracę o charakterze operacyjnym, jest niższy (wynosi 48,9 \%), ale i tak znacznie przewyższa ten odsetek w porównaniu z firmami, których właściciele wywodzą się z pozostałych korporacji (35\%), a zdecydowanie przewyższa odsetek firm kierowanych przez osoby bez takich doświadczeń (w przybliżeniu 22\%).

Tabela 8. Odsetek firm, które wprowadziły na rynek nowe produkty w zależności od doświadczenia zatrudnienia właścicieli w korporacjach, w tym w centrach usług

\begin{tabular}{|l|c|c|c|c|}
\hline \multicolumn{2}{|c|}{} & \multicolumn{2}{|c|}{$\begin{array}{c}\text { Firmy, które wprowadziły na } \\
\text { rynek nowe produkty }\end{array}$} & \\
\cline { 3 - 5 } & & tak & nie & \\
\hline $\begin{array}{l}\text { Firmy, których właściciele mają } \\
\text { doświadczenie związane z pracą } \\
\text { w korporacji }\end{array}$ & tak & 35,4 & 64,6 & $100 \%$ \\
\cline { 2 - 5 } & nie & 21,6 & 78,4 & $100 \%$ \\
\hline $\begin{array}{l}\text { Firmy, których właściciele mają } \\
\text { doświadczenie związane z pracą } \\
\text { w centrach usług }\end{array}$ & tak & 50,0 & 50,0 & $100 \%$ \\
\hline & nie & 22,4 & 77,6 & $100 \%$ \\
\hline
\end{tabular}

Źródło: opracowanie własne

Tabela 9. Odsetek firm, które wprowadziły na rynek nowe produkty w zależności od charakteru wykonywanej pracy przez właścicieli w korporacjach, w tym w centrach usług

\begin{tabular}{|c|c|c|c|c|}
\hline & & \multicolumn{2}{|c|}{$\begin{array}{l}\text { Firmy, które wprowadziły } \\
\text { na rynek nowe produkty }\end{array}$} & \\
\hline & & tak & nie & \\
\hline \multirow{3}{*}{$\begin{array}{l}\text { Firmy, których właściciele } \\
\text { mają doświadczenie związane } \\
\text { z pracą w korporacji o określonej } \\
\text { charakterystyce }\end{array}$} & Praca operacyjna & 35,0 & 65,0 & $100 \%$ \\
\hline & $\begin{array}{l}\text { Zarządzanie } \\
\text { zespołem/działem }\end{array}$ & 40,0 & 60,0 & $100 \%$ \\
\hline & Zarządzanie firmą & 42,1 & 57,9 & $100 \%$ \\
\hline \multirow{3}{*}{$\begin{array}{l}\text { Firmy, których właściciele mają } \\
\text { doświadczenie związane z pracą } \\
\text { w centrach usług o określonej } \\
\text { charakterystyce }\end{array}$} & Praca operacyjna & 48,9 & 51,7 & $100 \%$ \\
\hline & $\begin{array}{l}\text { Zarządzanie } \\
\text { zespołem/działem }\end{array}$ & 60,0 & 40,0 & $100 \%$ \\
\hline & Zarządzanie firmą & 100,0 & 0,0 & $100 \%$ \\
\hline
\end{tabular}

Źródło: opracowanie własne

Dość jednoznaczny wydaje się także wniosek, że właściciele wywodzący się z centrów usług, bez względu na rodzaj wykonywanych obowiązków, częściej wprowadzają na rynek nowe produkty niż ci właściciele, którzy pracowali w korporacjach. Wśród nich najczęściej nowe produkty wprowadzały firmy, których właściciele pracowali w działach badawczo-rozwojowym i sprzedaży. Sugeruje to występowanie efektów wynikających z transferu wiedzy przez bezpośredni transfer kapitału ludzkiego - wiedzy przydatnej do realizowania działań rozwojowych mikro-, małych i średnich firm. 
Warto przyjrzeć się zatem oddziaływaniu, jakie wywierają pracownicy o doświadczeniach korporacyjnych na rozwój firm. Dane obrazujące to zjawisko zestawiono w tabeli 10 .

Tabela 10. Odsetek firm, które prowadziły na rynek nowe produkty w zależności od doświadczenia zatrudnienia pracowników w korporacjach, w tym w centrach usług

\begin{tabular}{|c|c|c|c|c|}
\hline & & \multicolumn{2}{|c|}{$\begin{array}{l}\text { Firmy, które wprowadziły na } \\
\text { rynek nowe produkty }\end{array}$} & \\
\hline & & tak & nie & \\
\hline \multirow{3}{*}{$\begin{array}{l}\text { Firmy, których pracownicy } \\
\text { mają doświadczenie związane } \\
\text { z pracą w korporacji o określonej } \\
\text { charakterystyce }\end{array}$} & tak & 37,5 & 62,5 & $100 \%$ \\
\hline & nie & 21,2 & 78,8 & $100 \%$ \\
\hline & & tak & nie & \\
\hline \multirow{4}{*}{$\begin{array}{l}\text { Firmy, których pracownicy mają } \\
\text { doświadczenie związane z pracą } \\
\text { w centrach usług o określonej } \\
\text { charakterystyce }\end{array}$} & tak & 100,0 & 0,0 & $100 \%$ \\
\hline & nie & - & - & $100 \%$ \\
\hline & & 22,9 & 77,1 & $100 \%$ \\
\hline & Ogółem & 23,0 & 77,0 & $100 \%$ \\
\hline
\end{tabular}

Źródło: opracowanie własne

Wyniki przeprowadzonej analizy wskazują tutaj zaskakujące rezultaty, choć ich interpretacja z uwagi na rozmiar próby powinna być traktowana z pewną ostrożnością. Pokazują one, że zachodniopomorskie firmy sektora MMŚP, które zatrudniły pracowników wywodzących się z centrów usług, znacznie częściej wprowadziły na rynek nowe usługi (100\% takich firm) niż podmioty, które zatrudniły pracowników z doświadczeniem pracy w korporacji $(37,5 \%)$. Dla porównania, jedynie co piąta firma z regionu $(23,0 \%)$ wprowadziła na rynek nowe produkty. Sugeruje to, że podmioty gospodarcze zatrudniające pracowników z doświadczeniem w pracy w centrach usług znacznie częściej wprowadzają na rynek nowe produkty niż pozostałe przedsiębiorstwa (Chi kwadrat $=11,148)$. Jakkolwiek współwystępowanie omówione powyżej należy uznać za bardzo słaby związek statystyczny (R Pearsona = -0,001) - konieczny do potwierdzenia w dalszych badaniach - wydaje się, że przedstawione ustalenia mogą mieć odzwierciedlenie w rzeczywistości.

\section{PoDsumOWANIE}

Przeprowadzona analiza pozwala wnioskować, że rozwój nowoczesnych usług biznesowych ma pozytywny wpływ na akumulację wiedzy w regionie i pozwala czerpać z tej wiedzy lokalnie funkcjonującym podmiotom, w tym z sektora MMŚP. Okazuje się bowiem, że mniejsze lokalne podmioty, korzystające z wiedzy ukrytej pozyskanej w ramach transferu (poprzez transfer ludzi) z międzynarodowych centrów usług, osiągają statystycznie lepsze wyniki w zakresie innowacyjności oraz generalnie rozwoju mierzonego w wartościach finansowych niż te, które z takiej wiedzy nie korzystają.

Wyjaśnienia takiego stanu rzeczy można dopatrywać się w naturalnych przewagach, jakie te firmy czerpią z wcześniej zakumulowanych doświadczeń. Również inne wyniki badań wskazują na występowanie zależności rozwojowych wynikających z poprzednich doświadczeń przedsiębiorczych (np. Łobacz, Głodek, 2018). Ponadto istotne 
wydaje się być w tym kontekście znaczenie znajomości rynków i ich niezaspokojonych potrzeb, często również połączone z bezpośrednią znajomością klientów międzynarodowych. Przewagi te są dodatkowo powiązane z profesjonalnym podejściem do zarządzania, w ujęciu przedsiębiorczym, stosowanym jednak z elastycznością wynikającą z uwolnienia od biurokratycznych procedur typowych dla korporacji.

Głębsza analiza pozwala ponadto wnioskować, że innowacyjność i rozwój MMŚP korzystających z wiedzy transferowanej bezpośrednio z firm o charakterze korporacyjnym, w tym szczególnie z centrów usług, rzadko ma podłoże technologiczne i niezwykle rzadko opiera się na nowej wiedzy, która powstaje wewnątrz lub wokół dużej organizacji. Oznacza to, że prawdopodobnie MMŚP, które rozwijają się w oparciu o wiedzę pochodzącą z dużych organizacji usługowych, nie wykorzystują ścieżki rozwoju opisanej w odniesieniu do przedsiębiorstw o wysokiej intensywności wiedzy (knowledge-intensive enterprices), opierającej się na połączeniu okazji rynkowych, technologicznych i instytucjonalnych (Głodek, 2018; Łobacz, 2018; Radosevic, Yoruk, 2019). W odróżnieniu, wydaje się, że firmy te kształtują swoją konkurencyjność w oparciu o bogatą wiedzę rynkową, skutkującą trafną diagnozą potrzeb klienta oraz łatwym dostępem do pierwszych dużych klientów, a także sieci powiązań z potencjalnymi partnerami rynkowymi i tym samym łatwiejszy dostęp do wysokojakościowych i efektywnych kosztowo zasobów.

Wyniki badania sugerują ciekawy obraz rzeczywistości. Z perspektywy badacza trudne do wyjaśnienia jest silne zdeterminowanie znaczenia transferu wiedzy z dużym firm o charakterze usługowym w stosunku do ogółu przedsiębiorstw o charakterze korporacyjnym zlokalizowanych na tym samym terenie. Jedną z przypuszczalnych odpowiedzi może być większa podatność niektórych sektorów, rodzajów działalności, które wykazują większą podatność na występowanie transferu kapitału ludzkiego pomiędzy dużymi a małymi podmiotami oraz z definicji większą dynamikę wzrostu. Zagadnienie to warto byłoby pogłębić w dalszych studiach nad opisanym problemem.

\section{Literatura \\ Referencces}

ABSL (2016). Raport Sektor nowoczesnych usług biznesowych w Polsce 2016 przygotowany przez Związek Liderów Sektora Usług Biznesowych.

Acs, Z.J., Braunerhjelm, P., Audretsch, D.B., Carlsson, B. (2009). The knowledge spillover theory of entrepreneurship. Small Business Economy, 32, 15-30.

Arrow, K. (1962). The economic implications of learning by doing. The Review of Economic Studies, 29(3), 155-173.

Barney, J.B. (1992). Firm resources and sustained competitive advantage. Journal of Management, 17(1), 101-116.

Distanont, A., Khongmalai, O. (2018). The role of innovation in creating a competitive advantage. Kasetsart Journal of Social Sciences, doi: 10.1016/j.kjss.2018.07.009.

Dzikowska, M., Gorynia, M. (2012). Teoretyczne aspekty konkurencyjności przedsiębiorstwa w kierunku koncepcji eklektycznej. Gospodarka Narodowa, 4, 1-30.

Głodek, P. (2018). Akademicki spin off. Wiedza, zasoby i ścieżki rozwoju. Łódź: Wydawnictwo Uniwersytetu Łódzkiego.

Kunasz, M. (2006). Zasoby przedsiębiorstwa w teorii ekonomii. Gospodarka Narodowa, 10, 33-48.

Łobacz, K. (2012). Koncepcja oceny procesu komercjalizacji przedsięwzięć gospodarczych $w$ akademickich inkubatorach przedsiębiorczości. Szczecin: rozprawa doktorska, maszynopis powielony. 
Łobacz, K. (2015). Źródła wiedzy warunkującej innowacyjne działania przedsiębiorcze -konsekwencje dla sterowania kierunkami rozwoju systemów gospodarczych. Nierówności Społeczne a Wzrost Gospodarczy, 41, 412-431.

Łobacz, K. (2018). Innovating and growing service-based entrepreneurial business-development model based on european and asian case studies. European Journal of Service Management, $28,231-244$.

Łobacz, K., Głodek, P. (2018). Rozwój kapitału ludzkiego poprzez działania przedsiębiorcze: znaczenie przedsiębiorczości akademickiej. Horyzonty Wychowania, 17(44), 167-177.

Łobacz, K., Głodek, P., Stawasz, E., Niedzielski, P. (2016). Utilisation of business advice in small innovative firms - the role of trust and tacit knowledge. Entrepreneurial Business and Economics Review, 4(2), 117-138.

Navaretti, G.B., Venables, A.J. (2004). Multinational Firms in the World Economy. Princeton University Press.

Niedzielski, P., Łobacz, K. (red.) (2017). Centra usług w układach regionalnych. Szczecin: Wydawnictwo Naukowe Uniwersytetu Szczecińskiego.

Radosevic, S., Yoruk, E. (2019). Entrepreneurial orientation of knowledge - based enterprises in Central and East Europe. W: F. Malerba, Y. Caloghirou, M. McKelvey, S. Radosevic (red.). Dynamics of Knowledge-Intensive Entrepreneurship: Business strategy and public policy, Routledge - preprint.

Romer, P. (1986). Increasing returns and long-run growth. Journal of Political Economy, 94(5), 1002-1037.

Rugraff, E., Hansen, M.W. (2011). Multinational corporations and local firms in emerging economies. An Introduction. W: E. Rugraff, M.W. Hansen (red.). Multinational Corporations and Local Firms in Emerging Economies. Amsterdam University Press.

Sass, M. (2011). The impact of foreign direct investment in business services on the local economy. The case of Hungary. W: E. Rugraff, M.W. Hansen (red.) Multinational Corporations and Local Firms in Emerging Economies. Amsterdam University Press.

Schumpeter, J.A. (1939). Business cycles: a theoretical, historical, and statistical analysis of the capitalist process. New York and London: McGraw-Hill.

Stankiewicz, M.J. (2002). Konkurencyjność przedsiębiorstwa. Budowanie konkurencyjności przedsiębiorstwa w warunkach globalizacji. Toruń: Dom Organizatora.

Katarzyna Łobacz, doktor, Uniwersytet Szczeciński, Wydział Zarządzania i Ekonomiki Usług, Katedra Innowacji i Technologii Informacyjnych. Pracownik naukowy, autor książek i artykułów z obszaru innowacyjności, transferu i komercjalizacji wiedzy, przedsiębiorczości akademickiej, rozwoju kompetencji; doświadczona w realizacji projektów badawczych, w tym w zespołach międzynarodowych; silnie ukierunkowana na praktyczne zastosowanie wiedzy w postaci analiz wdrożeniowych, rozwoju ośrodków wsparcia innowacyjnej przedsiębiorczości, kierowania rozwojem karier studenckich itp.

Katarzyna Łobacz, PhD, University of Szczecin, Faculty of Management and Economics of Services, Department of Innovation and Information Technologies. University professor, author of publications, especially in the field of innovation, knowledge transfer and commercialisation, academic entrepreneurship, competence-based development; manager of numerous research projects; strongly oriented on practical applications of knowledge through expertise works, development of centres supporting innovation and entrepreneurship, development of students carrier pathways, etc.

\section{ORCID: 0000-0001-5038-1022}

Adres/address:

Uniwersytet Szczeciński

Wydział Zarządzania i Ekonomiki Usług

Katedra Innowacji i Technologii Informacyjnych

ul. Cukrowa 8, 71-004 Szczecin, Polska

e-mail: katarzyna.lobacz@wzieu.pl

Piotr Niedzielski, profesor, Uniwersytet Szczeciński, Wydział Zarządzania i Ekonomiki Usług. Pracownik naukowy, doświadczony badacz, szczególnie w obszarze innowacji usługowych, oceny projektów inwestycyjnych, innowacji w sektorze TSL; doświadczony konsultant firm i specjalista w obszarze komercjalizacji 
wiedzy z silnym naciskiem na rozwój regionalny; doświadczony w zarządzaniu małymi i dużymi organizacja$\mathrm{mi}, \mathrm{w}$ tym firmami oraz uczelniami wyższymi.

Piotr Niedzielski, PhD/professor, University of Szczecin, Faculty of Management and Economics of Services. University professor, experienced in research, especially in the field of service innovation, investment project appraisal, innovation in the TSL sector; experienced in consultancy and commercialisation of knowledge with strong focus on regional development; experienced in small and big organisation management (CEO in numerous companies, Head of Schools).

ORCID: 0000-0001-5024-4722

Adres/address:

Uniwersytet Szczeciński

Wydział Zarządzania i Ekonomiki Usług

ul. Cukrowa 8, 71-004 Szczecin, Polska

e-mail: piotr.niedzielski@wzieu.pl 